\title{
Osmotic adjustment, stomata morphology and function show contrasting responses to water stress in mesic and hydric grasses under elevated $\mathrm{CO}_{2}$ concentration
}

\author{
S.W. MWENDIA ${ }^{*,+}$, I.A.M. YUNUSA ${ }^{* * * * *}$, B.M. SINDEL ${ }^{* *}$, R.D.B. WHALLEY ${ }^{* *}$, and J.J. BRUHL** \\ International Center for Tropical Agriculture, Africa Regional Office, P.O. Box 823-00621, Nairobi, Kenya* \\ School of Environmental and Rural Science, University of New England, Armidale, NSW, 2351, Australia** \\ Graham Centre for Agricultural Innovation, Charles Sturt University, Panorama Avenue, Bathurst NSW 2795, \\ Australia
}

\begin{abstract}
The physiological response of two species of grasses with $\mathrm{C}_{3}$ and $\mathrm{C}_{4}$ mechanisms syndromes, Napier grass (Pennisetum purpureum Schumach $\times$ Pennisetum glaucum (L.) R. Br) and hydric common reed grass (Phragmites australis (Cav.) Trin. Ex Steud) was examined under ambient $\left(\mathrm{aCO}_{2}\right)$ and elevated $\mathrm{CO}_{2}\left(\mathrm{eCO}_{2}\right)$, in combination with water and temperature stress treatments. Under $\mathrm{eCO}_{2}$ and subjected to water and temperature stress, the Napier grass maintained higher daytime leaf water potential (LWP) by reducing transpiration $(E)$ and executing larger osmotic adjustment (OA) at an average of $0.85 \mathrm{MPa}$ compared with $0.42 \mathrm{MPa}$ for common reed; carbon assimilation $\left(P_{\mathrm{N}}\right)$ was thus higher for the Napier grass. Under $\mathrm{aCO}_{2}$ and low temperature, water stress induced no significant differences in OA between the grasses, but Napier grass still had higher $\mathrm{P}_{\mathrm{N}}$ than that of common reed. Recovery in LWP and $P_{\mathrm{N}}$ following re-watering of water-stressed plants was more rapid in Napier grass than that in the common reed; the former had also higher water-use efficiency due to its low specific water use (water use/leaf area) that was just a fraction (less than 6\%) that of the common reed. Exposure of common reed to $\mathrm{eCO}_{2}$ reduced stomata number, but increased it in the Napier grass, especially when subjected to water stress and high temperature. Exposure to $\mathrm{eCO}_{2}$ enhanced $\mathrm{OA}$ capacity and $E$ control in Napier grass resulting in superior physiological profile over the common reed subjected to water and heat stress.
\end{abstract}

Additional key words: heat stress; leaf water potential; water-use efficiency.

\section{Introduction}

Physiological and productivity responses to elevated atmospheric carbon dioxide concentration $\left(\mathrm{eCO}_{2}\right)$, temperature stress, and aridity can differ markedly between plant species, particularly, between $\mathrm{C}_{3}$ and $\mathrm{C}_{4}$ species. Giridhar and Samireddypalle (2015) postulated that $\mathrm{eCO}_{2}$ could promote dry matter accumulation in $\mathrm{C}_{3}$ and $\mathrm{C}_{4}$ species. The assertion has been confirmed by authors including Ward et al. (1999) and Liu et al. (2014) who observed enhanced photosynthesis and growth in the mesic Abutilon theophrasti $\left(\mathrm{C}_{3}\right)$ and Amaranthus retroflexus $\left(\mathrm{C}_{4}\right)$ under raised $\mathrm{CO}_{2}$ concentration, but without water stress. However, a combination of $\mathrm{eCO}_{2}$ and drought restrained stomatal conductance in mesic Glycine max $\left(\mathrm{C}_{3}\right)$, Sorghum bicolor $\left(\mathrm{C}_{4}\right)$, and Pascopyrum smithii $\left(\mathrm{C}_{3}\right)$ (Wall et al. 2001, Lecain et al. 2003, Bernacchi et al. 2007), similar to the riparian Osmunda regalis (Lammertsma et al. 2011).

Osmotic adjustment (OA) assists plants to maintain water uptake for tissue hydration when subjected to limited water supply. This attribute differs in its responses between species when subjected to drought conditions or elevated $\mathrm{CO}_{2}$ concentration. For instance, Nilsen et al. (1983) observed increased OA in mesic Prosopis glandulosa, similar to Triticum durum Desf. (Bajji et al. 2001) when the plants underwent a water-stress period. Essentially, this entails a decrease in cell sap osmotic potential resulting from a net increase in intracellular solutes rather than from a loss of cell water (Blum et al. 1996).

In addition to physiological changes, water stress alters morphological characteristics of leaf and stomata that often differ between plants of contrasting photosynthetic pathways (Ward et al. 1999, Fernandéz et al. 2002, Karkanis et al. 2011). For instance, while $A$.

Received 22 February 2018, accepted 4 July 2018.

${ }^{+}$Corresponding author; e-mail: mwendia2007@gmail.com

Abbreviations: $\mathrm{aCO}_{2}$ - ambient carbon dioxide concentration; $d f$ - degrees of freedom; $\mathrm{eCO}_{2}-$ elevated carbon dioxide concentration; $E$ - transpiration; LA - leaf area; LWP - leaf water potential; OA - osmotic adjustment; $P_{\mathrm{N}}$ - carbon assimilation; $r$ - correlation coefficient; SA - total stomatal area; SAI - stomatal area index; SD - stomata density; SWU - specific water use; $\mathrm{SBP}$ - specific biomass production; WU - water use; WUE - water-use efficiency.

Acknowledgements: We would like to acknowledge the Australian Agency for International Development (AUSAID) for financial support to do the work through Australian Awards. Technical support from Mick Faint, George Henderson, and Leanne Lisle from the School of Environmental and Rural Science, University of New England, Australia is highly appreciated. We acknowledge the useful comments from the three anonymous reviewers, which has helped to improve the manuscript. 
retroflexus $\left(\mathrm{C}_{4}\right)$ exposed to drought retained a larger leaf area and lower leaf water potential, A. theophrasti $\left(\mathrm{C}_{3}\right)$ shed more leaves presumably to reduce transpiration and maintain high leaf water potential in remaining leaves (Ward et al. 1999). Exposure of these two species to elevated (70 $\mathrm{Pa} \approx 690 \mathrm{ppm}$ ) compared to ambient (35 $\mathrm{Pa} \approx 345 \mathrm{ppm}) \mathrm{CO}_{2}$ concentration amplified water stress and reduced net photosynthesis in $A$. retroflexus, which had lower stomatal conductance, when compared with the $A$. theophrasti. Species with the $\mathrm{C}_{4}$ photosynthetic pathway, exhibit low photorespiration because phosphoenolpyruvate carboxylase refixes photorespired $\mathrm{CO}_{2}$ (Lambers 2008), contributing to maintaining a high wateruse efficiency (Ripley et al. 2007), as the refixed $\mathrm{CO}_{2}$, which drives growth, is at no additional transpiration cost. The $\mathrm{C}_{4}$ species are known to lower $\mathrm{CO}_{2}$ assimilation, well below that achieved by $\mathrm{C}_{3}$ species when water-stressed, and have been associated with the decreasing abundance of $\mathrm{C}_{4}$ species along gradients of declining rainfall (Ripley et al. 2007). In other examples, an exposure to $\mathrm{eCO}_{2}$ increased by $33 \%$ stomatal density in a mesic $\mathrm{C}_{3}$ Salvia pitcheri compared to a $25 \%$ reduction in the mesic $\mathrm{C}_{4}$ grass Andropogon gerardii (Knapp et al.1994). In the same study, $\mathrm{eCO}_{2}$ increased the adaxial/abaxial ratio for A. gerardii to 0.058 from 0.015 obtained under ambient $\mathrm{C}$ $\mathrm{O}_{2}$ concentration $\left(\mathrm{aCO}_{2}\right)$. Increases in stomatal density likely happens to enhance carbon assimilation and possibly offset constrained stomatal conductance under $\mathrm{eCO}_{2}$ (Eamus and Jarvis 1989, Tyree and Alexander 1993, Lambers 2008).

While most work has shown that $\mathrm{C}_{3}$ and $\mathrm{C}_{4}$ plants differ in physiological responses, and $\mathrm{C}_{4}$ is more efficient in water use and dry matter accumulation, they were undertaken with mesic species. Limited findings on comparison between mesic and hydric grasses exist. Such information would increase understanding on how these grasses would respond to global warming characterised by increasing temperatures and atmospheric carbon dioxide concentrations. In developing economies, which rely more on agriculture (Giridhar and Samireddypalle 2015) and more likely to experience effect of global warming, grasses are essential for livestock production. Production and understanding how grasses are likely to be affected is important.

In this study, we purposely compared the impact of two concentrations of $\mathrm{CO}_{2}$ and two temperature regimes on the mesic $\mathrm{C}_{4}$ Napier grass and the hydric $\mathrm{C}_{3}$ common reed subjected to water stress through three growth cycles in order to understand how they respond to a combination of water stress, high temperature, and elevated $\mathrm{CO}_{2}$. Common reed grass ( $P$. australis) is a $\mathrm{C}_{3}$ hydric species and is possibly the most widespread species in the world ranging from the tropics to the arctic regions and occurring on every major land mass except Antarctica, and has been used by human beings since prehistoric times (Köbbing et al. 2013). It occurs at wet sites with water levels from several meters below the soil surface up to $1 \mathrm{~m}$ deep and has therefore been described as a hydric species, but it also occurs in desert regions such as Death Valley in California and in Central Australia (Pearcy et al. 1974, Mallett et al. 2002, Köbbing et al. 2013). It can be an invasive species and there are important physiological differences between invasive and non-invasive populations in the eastern parts of the USA (Mozdzer and Zieman 2010). On the contrary, Napier grass $[P$. purpureum Schumach x $P$. glaucum (L.) R. Br] (Mwendia et al. 2013) is restricted to the tropical and sub-tropic regions, and can thrive from sea level to about 2,000 m (Boonman 1993). Both species are variably used for fodder (Gucker 2008, Tudsri et al. 2002), with Napier grass predominantly used in intensified livestock production systems in developing countries under the tropical environment. However, common reed becomes important fodder source especially during dry seasons. The specific aim of our study was to assess impact of water stress on the two grasses when exposed to different concentrations of atmospheric $\mathrm{CO}_{2}$ concentration and temperature by determining: (1) waterstress indices and carbon assimilation at different ages of the grasses, (2) recovery in tissue water status and carbon assimilation following alleviation of the water stress, and (3) morphological characteristics of the leaves and the stomata.

\section{Materials and methods}

Grasses used and experimental setup: Napier grass, $c v$. Bana, which is an infertile interspecific hybrid between P. purpureum Schumach and P. glaucum (L.) R. Br. was used along with common reed (P. australis (Cav.) Trin. Ex Steud) in this study. The Napier grass was sourced from Atherton, Australia $\left(17.2625^{\circ} \mathrm{S}, 145.4769^{\circ} \mathrm{E}\right)$ described previously by Mwendia et al. (2013). The common reed was collected from the bank of a creek on the campus of the University of New England, New South Wales, Australia $\left(30.4867^{\circ} \mathrm{S}, 151.6430^{\circ} \mathrm{E}\right)$ and is possibly less invasive than the invasive population studied in North America by Mozdzer and Zieman (2010).

The grasses were planted using splits of uniform sizes, into large plastic bins $(0.39 \mathrm{~m}$ in diameter, $0.46 \mathrm{~m}$ depth). The bins were filled with $50 \mathrm{~kg}$ of sandy alfisol soil (Klingebiel and Montgomery 1961) collected from the Trevenna University research farm used in an earlier study (Mwendia et al. 2013). The soil was ground to pass a $10-\mathrm{mm}$ sieve, weighed, and put in bins. The potted soil was supplied with diammonium phosphate fertilizer $(18: 20: 0, \mathrm{~N}: \mathrm{P}: \mathrm{K})$ at a rate of $13 \mathrm{~g}$ per bin, equivalent to $26 \mathrm{~kg}(\mathrm{P}) \mathrm{ha}^{-1}$ at the planting of the grasses. The soil surface in the bins was mulched with alkathene beads to minimize evaporation. The potted grasses were then arranged in two adjacent glasshouse bays with one bay maintained at $\mathrm{aCO}_{2}$ and the other at $\mathrm{eCO}_{2}$. $\mathrm{eCO}_{2}$ concentration was achieved by supplying $\mathrm{CO}_{2}$ gas through an overhead ventilation system running from cylinders kept outside the glasshouse. $\mathrm{CO}_{2}$ concentrations at the two glasshouse bays were monitored with a $\mathrm{CO}_{2}$-temperature-humidity sensor with an inbuilt data logger (CO210, Extech, New Hampshire, USA). Desired temperatures were maintained and automatically logged via an inbuilt air conditioning systems in the bays (Honeywell International Inc., Morristown, NJ, USA). Transition between the set temperature limits occurred over 
3-h periods in the morning (07:00-10:00 h) and evening (19:00-20:00 h) in both glasshouse bays. This setup was used for a series of experiments described below.

Experiment I. Effects of water stress under $\mathrm{eCO}_{2}$ at $15 / 25^{\circ} \mathrm{C}$ : Grasses (8 bins for each species) were planted on 4 April 2013, and initially allowed to establish for 3 weeks until 27 May. The bins were spaced within the glasshouse bays in a completely randomised design and maintained so throughout the experiments. Measurements of LWP were made on 22 and 27 May, i.e. approximately 17 ( 2 weeks) and $22 \mathrm{~d}(\sim 3$ weeks) after watering withdrawal. The bins were then fully rewatered on 27 May and left for 1 week before leaf samples were taken for osmotic potential measurements on 4 June. The bins were again watered on 5 June and the leaves sampled to repeat the osmotic potential measurements. On 6 June, stomata characteristics were determined on the topmost fully expanded leaf from each bin. Procedures for these measurements are described below. The grasses were then cut on 6 June (i.e. seven weeks after planting) at the alkathene beads level and growth variables (dry matter and its partitioning) were determined (described below).

Experiment II. Effects of $\mathrm{eCO}_{2}$ and temperature on recovery from water stress: After harvesting the experiment 1 , the bins were left in their respective glasshouse bays for the further experiment. Temperature in the $\mathrm{eCO}_{2}$ bay was raised to $17 / 30^{\circ} \mathrm{C}$, while the other bay was kept at $\mathrm{aCO}_{2}$ and $15 / 25^{\circ} \mathrm{C}$. The grasses were allowed to regrow, and watered every $7 \mathrm{~d}$ until 2 July (approx. four weeks after regrowth commenced) when watering was withdrawn until 7 July, when LWP was measured before the grasses were watered later that day. The LWP measurement was repeated on 8 July. Carbon assimilation and $E$ were measured on 1 July after a week of watering withdrawal and repeated a day after watering on 8 July. The temperature and vapour pressure deficit on 1 July were $27.2^{\circ} \mathrm{C}$ and $2.37 \mathrm{kPa}$ ( $\mathrm{aCO}_{2}$ bay), respectively, while similar values in $\mathrm{eCO}_{2}$ were $29.6^{\circ} \mathrm{C}$ and $2.85 \mathrm{kPa}$, when the measurements were made. On 8 July, the values were $30.3^{\circ} \mathrm{C}$ and $3.62 \mathrm{kPa}$ in $\mathrm{aCO}_{2}$ bay $v s .31 .9^{\circ} \mathrm{C}$ and $3.97 \mathrm{kPa}$ in $\mathrm{eCO}_{2}$ bay. The grasses were cut on $10 \mathrm{July}$, and then watered regularly to allow regrowth for the next experiment.

Experiment III. Water-stress responses under $\mathrm{eCO}_{2}$ and $17 / 30^{\circ} \mathrm{C}$ : The two bays were kept at their respective (ambient or elevated) $\mathrm{CO}_{2}$ concentration but the temperature of the cool bay was raised to $17 / 30^{\circ} \mathrm{C}$. After the experiment II harvest, the bins were fully watered and then left for two weeks until 31 July without watering, before watering on 7 August. Leaf water potential and gasexchange measurements were made on 31 July ( $21 \mathrm{~d}$ after watering withdrawal) and 9 August (2 d after watering). During these measurements, temperature and vapour pressure deficit were $31.9^{\circ} \mathrm{C}$ and $3.63 \mathrm{kPa}$, respectively, in $\mathrm{aCO}_{2}$ bay on $31 \mathrm{July}$, while similar values were $30.9^{\circ} \mathrm{C}$ and $3.25 \mathrm{kPa}$ in $\mathrm{eCO}_{2}$ bay. On 9 August, the values were $33.4^{\circ} \mathrm{C}$ and $4.65 \mathrm{kPa}$, respectively, in $\mathrm{aCO}_{2}$ bay $v s .31 .8^{\circ} \mathrm{C}$ and
$3.83 \mathrm{kPa}$, respectively, in $\mathrm{eCO}_{2}$ bay. Leaf samples were also taken on both days for determination of osmotic potential. Leaf samples for stomatal attributes were harvested on 14 August before cutting the grasses on that day, after five weeks of regrowth. Dry matter and its partitioning were assessed as in the experiment I.

Leaf water potential (LWP) measurements were made with a pressure chamber (1505D, PMS Instruments, Albany, USA). Sixteen samples, one from every experimental unit (bin) were excised from the youngest fully expanded leaf and immediately pressurized in the chamber and a reading recorded once water appeared on the excised edge protruding from the chamber. This was repeated during every round of LWP measurements.

Osmotic potential was measured on the youngest fully expanded leaves with a psychrometer (SC-10A, Decagon Devices, Pullman, WA, USA). A set of 16 leaf samples, one from every bin, and comprising 3 to 4 leaves, were harvested during the imposed water stress and after restoration of watering as described in the experiments I and III. The samples were transferred into zip-lock bags and frozen in liquid nitrogen. The psychrometer was calibrated with $\mathrm{NaCl}$ molarities $(0.1,0.3,0.5,0.7$, and 1.0) of known water potential. Before measurements, the leaf samples were removed from the liquid nitrogen and placed in clean tygon tubes of about 70-mm length and allowed to thaw. Thereafter, samples were pressed with a clamp to squeeze out the sap which was collected using syringes and quickly transferred into psychrometer aluminium cups whose sides were lined with filter paper. The cups were then loaded into the sample changer and allowed to equilibrate for $25 \mathrm{~min}$. Each sample was then sequentially lifted into the thermocouple orifice and the microvolt reading recorded when stable. These readings were converted into osmotic potential using calibration equations developed from the salt solutions. The difference between the osmotic potential of a well-watered and a water-stressed leaf sample was recorded as the osmotic adjustment, OA (Bajji et al. 2001).

Gas exchange: A portable photosynthesis system ( $L I-$ $6400 X T$, LI-COR Inc., Lincoln, USA) was used to determine instantaneous values of $P_{\mathrm{N}}, E$, and stomatal conductance $\left(g_{\mathrm{s}}\right)$ around midday $(11: 00-13: 00 \mathrm{~h})$ on the nominated days for the experiments. Sixteen readings, each from every bin, were made on the youngest fully expanded leaves during each measurement cycle. The system was set at a PAR value of $1,330 \mu \mathrm{mol}$ (photon) $\mathrm{m}^{-2} \mathrm{~s}^{-1}$. Instantaneous water-use efficiency (WUE) was derived by dividing the carbon assimilated by the amount of water transpired during the carbon assimilation.

Stomatal density, stomatal area, and stomatal area index (SAI): Stomatal density and size were measured on the fully developed second youngest leaf harvested from every bin (16) at the end of experiments I and III, and placed in labelled zip-lock bags stored in liquid nitrogen until needed for slide preparation. Leaves were removed 
from storage and allowed to thaw after which a section was cut (specimen) with a scalpel and placed in a petri dish. The surface of the specimen was gently scraped with the scalpel and washed with deionized water from a wash bottle until a clear tissue devoid of chlorophyll was achieved. If the target leaf surface was abaxial, scraping was done on the adaxial side and vice versa. The clear tissue was placed on the glass slide and a drop of distilled water added and a cover slip placed over it. The preparation was viewed under a compound microscope (Optika B-157, Ponteranica, Italy) at $40 \times$ magnification. The stomata within the field-of-view were counted and the dimensions (length and breadth) of 5 randomly selected stomata were measured and recorded. This procedure was repeated for all the samples on both abaxial and adaxial leaf surfaces. Stomatal area index (SAI) was derived as:

$$
\mathrm{SAI}=\frac{\text { Total stomatal area }(\mathrm{SA})}{\text { Leaf area }(\mathrm{LA})}
$$

Dry matter yield, leaf area, and leaf to stem ratio: Dry matter yield (DM), leaf area (LA), and a leaf to stem ratio were determined at the end of both experiments I and III. The grasses were harvested by cutting at the level of alkathene beads in each bin and weighed fresh. Samples of at least three tillers from each bin (16) were picked and manually separated into stems and leaves which were then weighed fresh and again after drying in an oven at $60^{\circ} \mathrm{C}$ for $48 \mathrm{~h}$. Also, a single leaf from each bin was taken to obtain their fresh mass and leaf area. The latter was undertaken with a leaf area meter (CI-202, CID BioScience, Washington, USA). The single leaves were then oven-dried as described above. The area/mass ratio for an individual leaf was used to determine the total area of leaves from the total leaves mass of leaves in each bin. The total DM yield for each bin was estimated from the total fresh masses of all the tillers using fresh/dry masses of the sub-sampled tillers. Leaf to stem ratio was based on the DM of the partitioned leaves and stems from each bin.

Water use: The water use for each bin was estimated by summation of water applied to each bin plus water available in the soil at planting, less the water in the soil and plants at the end of the experiment. Soil samples of about $75 \mathrm{~g}$ were taken before planting and at the end of the experiment and water content determined by oven-drying at $105^{\circ} \mathrm{C}$ for $48 \mathrm{~h}$. Water use [1] was converted to millimetre depth by dividing water use $\left[\mathrm{mm}^{3}\right]$ by bin surface area $\left[\mathrm{mm}^{2}\right]$. Productivity WUE was achieved as the ratio of dry matter accumulated over water used, during accumulation of that dry matter.

Statistical analysis: All data were collated in Excel Microsoft software and checked for entry errors. The data were imported into Minitab statistical software (Minitab Inc., 2007) where means and their standard errors were computed including regression analysis and their plots. Analysis of variance (ANOVA) was done in GenStat VSN International (2015), and means separated by least significant difference (LSD). Correlation coefficients $(r)$ were derived from pooled data from the experiment I and III, for Napier grass and common reed separately, on midday leaf water potential, osmotic adjustment, $P_{\mathrm{N}}, g_{\mathrm{s}}$, stomatal density, stomatal area, and stomatal area index. Significance was confirmed from Pearson's correlation coefficient table at $P<0.05$ and at 14 degrees of freedom $d f(n-2)$. Where applicable, graphs were plotted in Excel Microsoft software or GenStat.

\section{Results}

Ambient conditions inside the glasshouse bays: The ambient conditions in the glasshouse bays during the three experimental periods were generally as planned. The mean temperatures under both the low and high temperature conditions were stable during the course of the three experiments although there was some increase in the $\mathrm{CO}_{2}$ concentration in the $\mathrm{eCO}_{2}$ bay during the experiment III (Table 1).

Responses to water stress under $\mathbf{e C O}_{2}$ at $15 / 25^{\circ} \mathrm{C}$ : Leaf water potential was less negative in Napier grass than that of common reed under either $\mathrm{aCO}_{2}$ or $\mathrm{eCO}_{2}$ and at predawn and midday after two weeks of watering withdrawal (Fig.1A). With prolonging withdrawal to three weeks (Fig. $1 B$ ), both grass species had similar predawn LWP irrespective of $\mathrm{CO}_{2}$ concentration. However, by midday, Napier grass under $\mathrm{aCO}_{2}$ was more water-stressed than Napier grass under $\mathrm{eCO}_{2}$ or common reed under either $\mathrm{aCO}_{2}$ or $\mathrm{eCO}_{2}$ (Fig. $\left.1 B\right)$.

$P_{\mathrm{N}}$ was higher in Napier grass than that in common reed at two weeks following watering withdrawal, but only under $\mathrm{aCO}_{2}$ concentration, while both species had similar $P_{\mathrm{N}}$ under $\mathrm{eCO}_{2}$ (Fig. $1 C$ ). With the prolonged watering withdrawal, common reed had higher $P_{\mathrm{N}}$ than Napier grass

Table 1. Mean values $( \pm \mathrm{SE})$ for temperature $(\mathrm{T})$, carbon dioxide concentration, relative humidity, and vapour pressure deficit $(\mathrm{VPD})$ in the glasshouse bays during the first, second, and third experiments. $\mathrm{aCO}_{2}-$ ambient $\mathrm{CO}_{2} ; \mathrm{eCO}_{2}-$ elevated $\mathrm{CO}_{2}$.

\begin{tabular}{|c|c|c|c|c|c|c|c|c|c|c|}
\hline \multicolumn{3}{|c|}{ Experiment } & \multicolumn{5}{|l|}{$\mathrm{aCO}_{2}$ bay } & \multicolumn{3}{|l|}{$\mathrm{eCO}_{2}$ bay } \\
\hline & $\begin{array}{l}\text { T regime } \\
{\left[{ }^{\circ} \mathrm{C}\right]}\end{array}$ & $\begin{array}{l}\mathrm{T} \\
{\left[{ }^{\circ} \mathrm{C}\right]}\end{array}$ & $\begin{array}{l}\mathrm{CO}_{2} \\
{[\mathrm{ppm}]}\end{array}$ & $\begin{array}{l}\text { Rel. humidity } \\
{[\%]}\end{array}$ & $\begin{array}{l}\mathrm{VPD} \\
{[\mathrm{kPa}]}\end{array}$ & $\begin{array}{l}\text { T regime } \\
{\left[{ }^{\circ} \mathrm{C}\right]}\end{array}$ & $\begin{array}{l}\mathrm{T} \\
{\left[{ }^{\circ} \mathrm{C}\right]}\end{array}$ & $\begin{array}{l}\mathrm{CO}_{2} \\
{[\mathrm{ppm}]}\end{array}$ & $\begin{array}{l}\text { Rel. humidity } \\
{[\%]}\end{array}$ & $\begin{array}{l}\text { VPD } \\
{[\mathrm{kPa}]}\end{array}$ \\
\hline I & $15 / 25$ & $20.5 \pm 0.1$ & $426 \pm 9.8$ & $39 \pm 0.2$ & $2.0 \pm 0$ & $215 / 25$ & $19.8 \pm 0.1$ & $563 \pm 6.7$ & $41 \pm 0.2$ & $1.9 \pm 0.02$ \\
\hline II & $15 / 25$ & $20.6 \pm 0.1$ & $424 \pm 0.3$ & $40 \pm 0.2$ & $2.0 \pm 0$ & $217 / 30$ & $22.5 \pm 0.1$ & $541 \pm 6.9$ & $35 \pm 0.2$ & $2.5 \pm 0.02$ \\
\hline III & $17 / 30$ & $23.4 \pm 0.1$ & $425 \pm 0.3$ & $30 \pm 0.2$ & $3.0 \pm 0$ & $217 / 30$ & $22.7 \pm 0.1$ & $601 \pm 9.1$ & $33 \pm 0.2$ & $2.7 \pm 0.02$ \\
\hline
\end{tabular}


2 WEEKS AFTER WATERING WITHDRAWAL

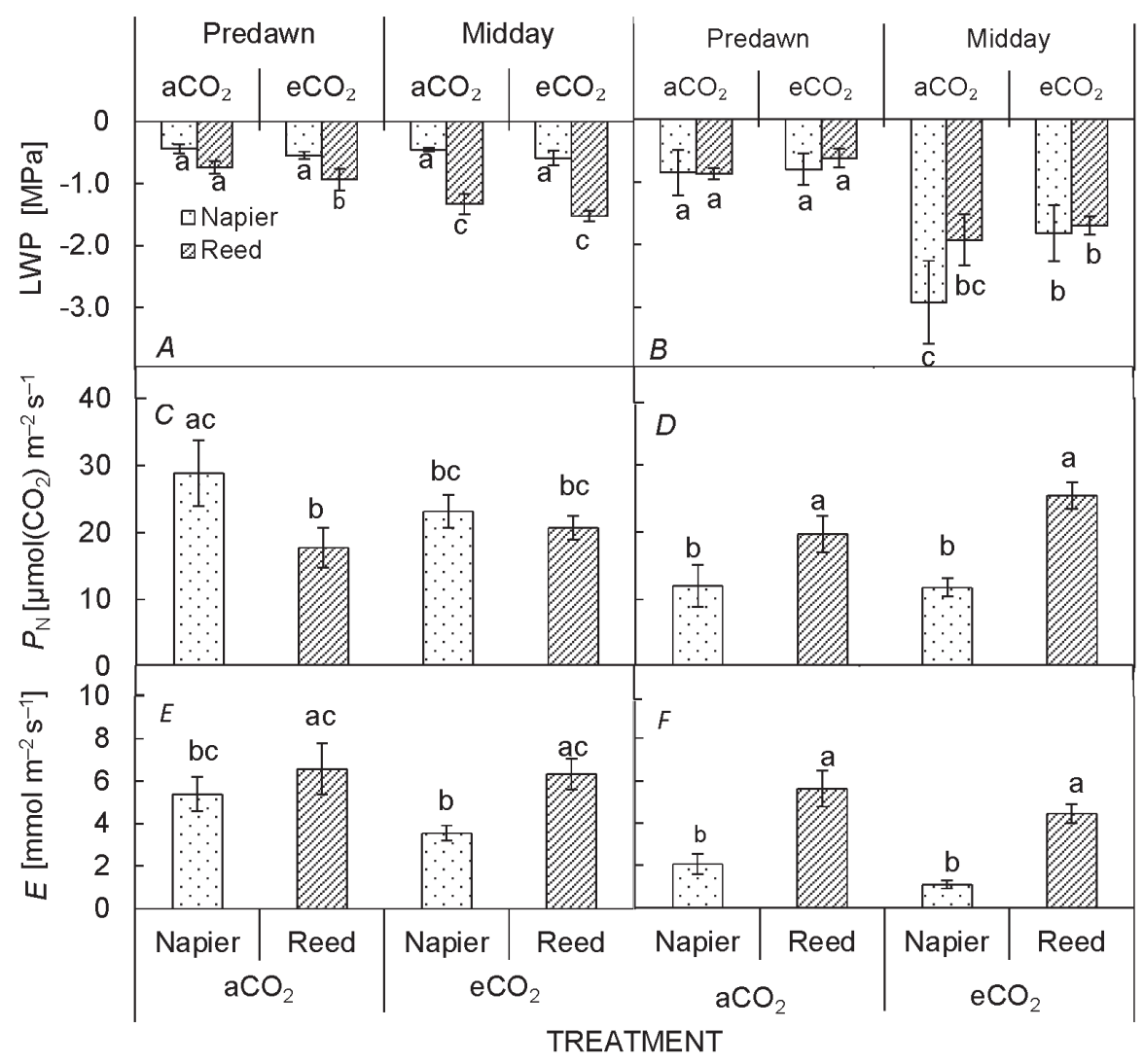

Fig. 1. Mean values $( \pm \mathrm{SE})$ for leaf water potential (LWP) measured at predawn and midday $(A, B)$, carbon assimilation $\left(P_{\mathrm{N}}\right)(C, D)$, and transpiration $(E)(E, \mathrm{~F})$ for three-week-old Napier grass and common reed under ambient $\left(\mathrm{aCO}_{2}\right)$ or elevated $\left(\mathrm{eCO}_{2}\right)$ carbon dioxide concentration under $15 / 25^{\circ} \mathrm{C}$, after two $(A, C, E)$ or three weeks $(B, D, F)$ of watering withdrawal.

Table 2. Mean values $( \pm \mathrm{SE}$ ) for osmotic potential $(\pi)$, osmotic adjustment $(\mathrm{OA})$, and instantaneous water-use efficiency (WUE) for Napier grass and common reed exposed to either ambient $\left(\mathrm{aCO}_{2}\right)$ or elevated $\left(\mathrm{eCO}_{2}\right)$ concentration of carbon dioxide and $15 / 25^{\circ} \mathrm{C}$ or $17 / 30^{\circ} \mathrm{C} .{ }^{1}$ Osmotic potential $(\pi)$ was measured after nine days (before watering) and one day after watering was restored. ${ }^{2} \mathrm{WUE}$ was obtained at two and three weeks without watering. ${ }^{3}$ Osmotic potential $(\pi)$ was measured after eight days (before watering) and one day after watering was restored. ${ }^{4} \mathrm{WUE}$ was obtained at three weeks before watering and two days after watering day. Means with different superscript in a column for each temperature level differ significantly $(P<0.05)$

\begin{tabular}{|c|c|c|c|c|c|c|}
\hline \multirow[t]{2}{*}{ Grass species } & \multirow[t]{2}{*}{$\mathrm{CO}_{2}$} & \multicolumn{2}{|l|}{$\begin{array}{l}\pi[-\mathrm{MPa}]^{1} \\
15 / 25^{\circ} \mathrm{C}\end{array}$} & \multirow[t]{2}{*}{$\mathrm{OA}[\mathrm{MPa}]$} & \multicolumn{2}{|c|}{ WUE $\left[\mu \mathrm{mol} \mathrm{mmol}{ }^{-1}\right]^{2}$} \\
\hline & & Before watering & After watering & & 2 weeks & 3 weeks \\
\hline \multirow{6}{*}{$\begin{array}{l}\text { Napier grass } \\
\text { Common reed } \\
\text { Napier grass } \\
\text { Common reed }\end{array}$} & \multirow[t]{2}{*}{$\mathrm{aCO}_{2}$} & $2.47 \pm 0.24^{\mathrm{a}}$ & $2.18 \pm 0.32^{\mathrm{a}}$ & $0.30 \pm 0.19^{\mathrm{a}}$ & $5.62 \pm 0.40^{\mathrm{b}}$ & $5.33 \pm 0.43^{b}$ \\
\hline & & $1.44 \pm 0.12^{\mathrm{b}}$ & $1.23 \pm 0.01^{\mathrm{b}}$ & $0.21 \pm 0.12^{\mathrm{a}}$ & $3.53 \pm 0.08^{c}$ & $2.73 \pm 0.24^{\mathrm{d}}$ \\
\hline & \multirow[t]{4}{*}{$\mathrm{eCO}_{2}$} & $2.18 \pm 0.28^{\mathrm{a}}$ & $1.86 \pm 0.18^{\mathrm{a}}$ & $0.32 \pm 0.14^{\mathrm{a}}$ & $11.06 \pm 0.73^{\mathrm{a}}$ & $6.54 \pm 0.51^{\mathrm{a}}$ \\
\hline & & $1.47 \pm 0.03^{b}$ & $1.13 \pm 0.05^{\mathrm{b}}$ & $0.34 \pm 0.06^{\mathrm{a}}$ & $5.81 \pm 0.51^{\mathrm{b}}$ & $3.27 \pm 0.19^{\mathrm{c}}$ \\
\hline & & \multicolumn{5}{|l|}{$17 / 30^{\circ} \mathrm{C}$} \\
\hline & & \multicolumn{3}{|l|}{$\pi[-\mathrm{MPa}]^{3}$} & \multicolumn{2}{|c|}{ WUE $\left[\mu \mathrm{mol} \mathrm{mmol}{ }^{-1}\right]^{4}$} \\
\hline Napier grass & $\mathrm{aCO}_{2}$ & $2.33 \pm 0.16^{\mathrm{b}}$ & $1.67 \pm 0.12^{\mathrm{bc}}$ & $0.66 \pm 0.06^{\mathrm{b}}$ & $2.45 \pm 0.57^{\mathrm{bc}}$ & $4.15 \pm 0.07^{\mathrm{b}}$ \\
\hline \multirow{3}{*}{$\begin{array}{l}\text { Common reed } \\
\text { Napier grass } \\
\text { Common reed }\end{array}$} & \multirow{3}{*}{$\mathrm{eCO}_{2}$} & $2.16 \pm 0.07^{c}$ & $1.80 \pm 0.13^{\mathrm{a}}$ & $0.38 \pm 0.09^{b}$ & $2.38 \pm 0.15^{\mathrm{c}}$ & $2.00 \pm 0.09^{\mathrm{d}}$ \\
\hline & & $2.61 \pm 0.11^{\mathrm{a}}$ & $1.76 \pm 0.03^{\mathrm{ac}}$ & $0.85 \pm 0.10^{\mathrm{a}}$ & $5.83 \pm 1.67^{\mathrm{a}}$ & $6.14 \pm 0.51^{\mathrm{a}}$ \\
\hline & & $2.05 \pm 0.20^{\mathrm{d}}$ & $1.63 \pm 0.07^{\mathrm{b}}$ & $0.42 \pm 0.14^{\mathrm{b}}$ & $2.79 \pm 0.32^{b}$ & $2.83 \pm 0.38^{b}$ \\
\hline
\end{tabular}

under either $\mathrm{aCO}_{2}$ or $\mathrm{eCO}_{2}$, while Napier grass maintained similar $P_{\mathrm{N}}$ across the two $\mathrm{CO}_{2}$ concentrations (Fig. $1 D$ ).

$E$ was higher in common reed than that of Napier grass at two weeks of watering withdrawal only under $\mathrm{eCO}_{2}$ (Fig. 1E). At three weeks of watering withdrawal, there was significantly reduced $E$ in Napier grass compared to common reed, particularly at the $\mathrm{eCO}_{2}$ (Fig. $\left.1 F\right)$.

Exposure to $\mathrm{eCO}_{2}$ reduced osmotic potential in Napier grass before watering and in common reed after watering at $15 / 25^{\circ} \mathrm{C}$ (Table 1 ). However, osmotic adjustment was similar in both grasses under $\mathrm{aCO}_{2}$ at $15 / 25^{\circ} \mathrm{C}$ (Table 2). Instantaneous water-use efficiency ( $\mathrm{WUE}_{\mathrm{I}}$ ) was higher for 


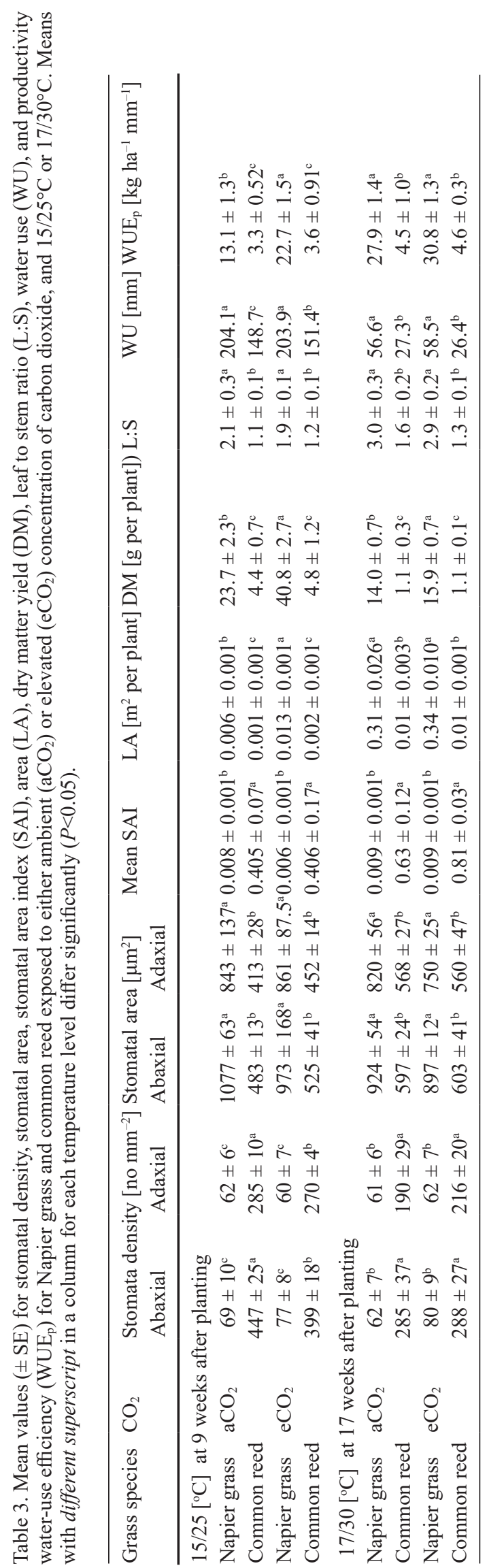

both species after two weeks of watering withdrawal than that in the third week. Water stress and $\mathrm{eCO}_{2}$ increased $\mathrm{WUE}_{\mathrm{I}}$ by $49 \%$ in Napier grass and $39 \%$ in common reed under the relatively low temperature of this experiment. A similar trend was observed in the productivity WUE $\left(\mathrm{kg} \mathrm{ha}^{-1} \mathrm{~mm}^{-1}\right)$ which increased by $42 \%$ in Napier grass and $8 \%$ in common reed exposed to $\mathrm{eCO}_{2}$ compared to $\mathrm{aCO}_{2}$ (Table 3).

Responses in stomata and leaf morphology to water stress at different $\mathrm{CO}_{2}$ concentrations and low temperature: Exposure to $\mathrm{eCO}_{2}$ at low temperatures did not affect stomatal density in Napier grass whereas in the common reed, stomatal density was significantly reduced by as much as $10 \%$ on abaxial and $5 \%$ on the adaxial surface (Table 3). The common reed generally had at least 4.5 times more stomata than Napier grass on either leaf surface under either $\mathrm{CO}_{2}$ concentration. Mean stomatal area on both leaf surfaces was $\sim 2$ times larger in Napier grass than that in common reed such that stomatal area index in common reed was $\sim 2.5$ times higher than that of Napier grass. Exposure to $\mathrm{eCO}_{2}$ at low temperatures had similar stomatal area, although there was an increase by $\sim 8 \%$ on the abaxial surface in both species and equally on the adaxial leaf surface in common reed, but only by $2 \%$ in Napier grass. Despite differences in stomatal density, stomatal area index (SAI) for the individual grasses was not affected by $\mathrm{CO}_{2}$ concentration, but the SAI of common reed was at least double that of Napier grass.

The leaf area in Napier grass under low temperature was 6 to $6 \frac{1}{2}$ times higher than that of common reed (Table 3). Napier grass maintained a larger leaf to stem ratio at $\mathrm{aCO}_{2}$ and $\mathrm{eCO}_{2}$ than that of reed. $\mathrm{eCO}_{2}$ increased biomass accumulation by $42 \%$ in Napier grass but only by $8 \%$ in common reed when compared with plants kept under $\mathrm{aCO}_{2}$. Napier grass had up to $8 \frac{1}{2}$ times higher biomass accumulation than that of common reed (Table 3 ).

Rapidity of the recovery of tissue water status under

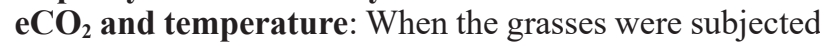
to water stress at 11 weeks of age in the experiment II (Fig. 2A,C,E), Napier grass generally had more negative LWP, and lower $P_{\mathrm{N}}$ and $E$ than that of common reed. Except predawn LWP under $\mathrm{aCO}_{2}$ and $15 / 25^{\circ} \mathrm{C}$, where the two grasses had similar LWP, Napier grass was more water-stressed than common reed (Fig. 2A). Upon rewatering, Napier grass recovered more readily in having less negative LWP than common reed at either predawn or midday under either of the $\mathrm{CO}_{2}$ concentrations or temperature levels, except for predawn at $\mathrm{aCO}_{2}$ and 15/25ㄷ (Fig. 2B).

Following watering withdrawal (Fig. 2C), common reed had higher $P_{\mathrm{N}}$ than that of Napier grass under either of the $\mathrm{CO}_{2}$ concentrations and temperature conditions. Upon rewatering (Fig. 2D), $P_{\mathrm{N}}$ was similar in Napier grass and common reed under $\mathrm{aCO}_{2}$ and low temperature, while common reed had similar $P_{\mathrm{N}}$ under $\mathrm{eCO}_{2}$ and high temperature. $E$ was higher in common reed than that of Napier grass under either of the temperature and $\mathrm{CO}_{2}$ conditions after watering withdrawal and upon watering 


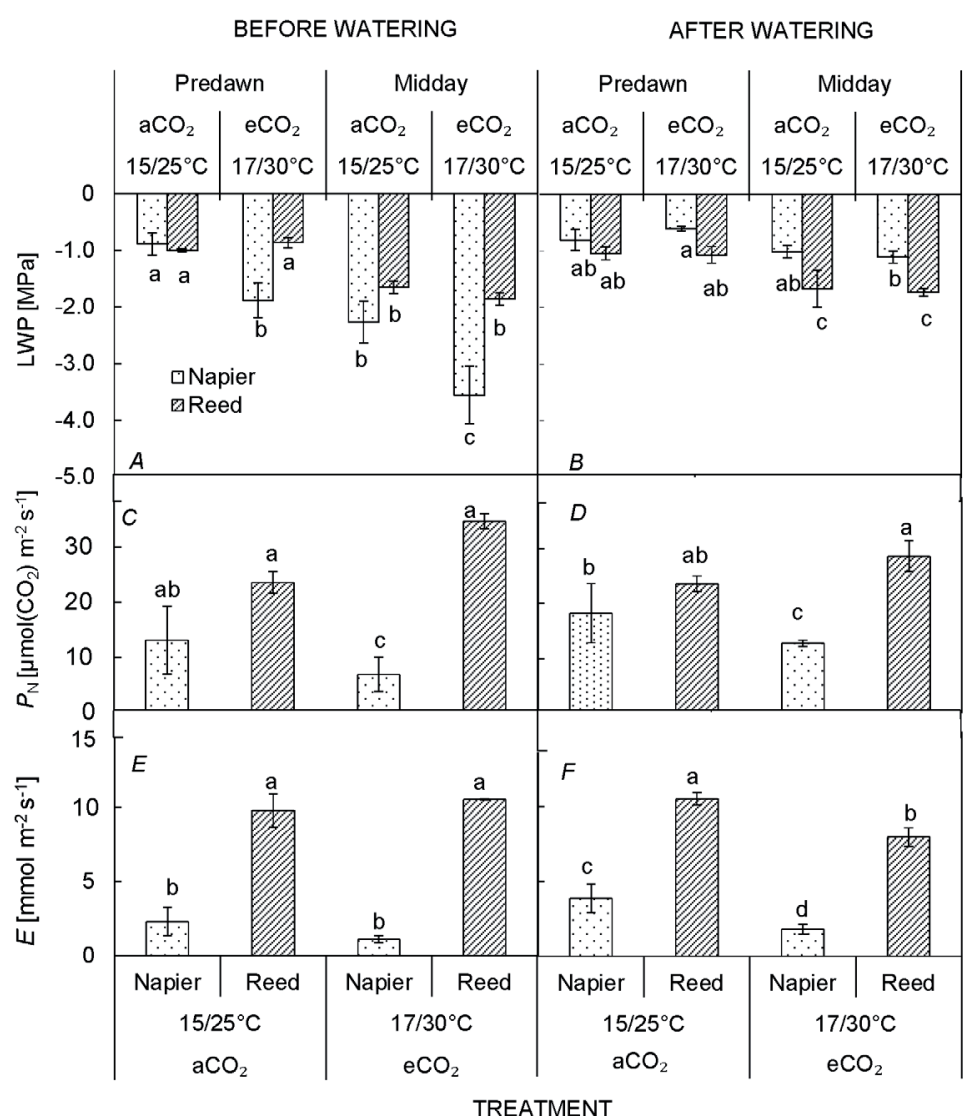

BEFORE WATERING

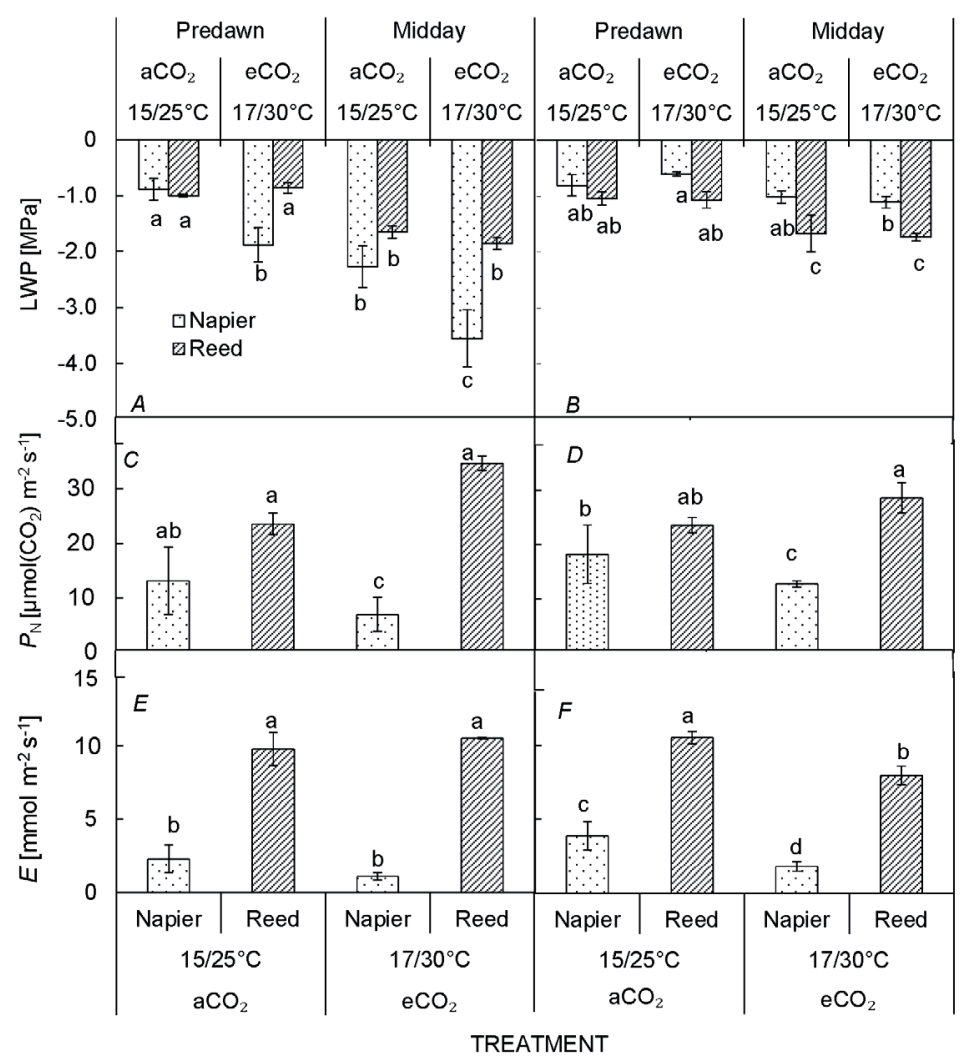

Fig. 2. Mean values $( \pm \mathrm{SE})$ for $(A, B)$ leaf water potential (LWP) measured at predawn and midday, $(C, D)$ carbon assimilation $\left(P_{\mathrm{N}}\right)$, and $(E, F)$ transpiration $(E)$ for 11 weeks old Napier grass and common reed under ambient $\left(\mathrm{aCO}_{2}\right)$ or elevated $\left(\mathrm{eCO}_{2}\right)$ concentration of carbon dioxide and $15 / 25^{\circ} \mathrm{C}$ or $17 / 30^{\circ} \mathrm{C}$. Both LWP and $\mathrm{CO}_{2}$ assimilation were measured one week after watering withdrawal (before watering) and a day after watering was restored.

Fig. 3. Mean values $( \pm \mathrm{SE})$ for $(A)$ leaf water potential (LWP) at predawn or midday, $(B)$ carbon dioxide assimilation $\left(P_{\mathrm{N}}\right)$, and $(C)$ transpiration $(E)$ for 15 weeks old Napier grass and common reed under ambient $\left(\mathrm{aCO}_{2}\right)$ or elevated $\left(\mathrm{eCO}_{2}\right)$ concentration of carbon dioxide following three weeks of watering withdrawal under $17 / 30^{\circ} \mathrm{C}$. 
Table 4. Correlation coefficients $(r)$ amongst midday leaf water potential (LWP), osmotic adjustment $(O A)$, carbon assimilation $\left(P_{\mathrm{N}}\right)$, stomatal conductance $\left(g_{\mathrm{s}}\right)$, transpiration $(E)$, stomatal density (SD), stomatal area (SA), and stomatal area index (SAI) for Napier grass and common reed under glasshouse conditions. Coefficients are significant at $P<0.1(*), P<0.05(* *)$ or $P<0.001(* * *)$; df $(n-2)=14$.

\begin{tabular}{|c|c|c|c|c|c|c|c|}
\hline $\begin{array}{l}\text { Variable } \\
\text { Napier grass }\end{array}$ & LWP & $\mathrm{OA}$ & $P_{\mathrm{N}}$ & $g_{\mathrm{s}}$ & $\mathrm{E}$ & SD & SA \\
\hline $\mathrm{OA}$ & 0.16 & & & & & & \\
\hline A & $0.38^{*}$ & -0.06 & & & & & \\
\hline$g_{\mathrm{s}}$ & 0.30 & 0.14 & $0.90^{* * * *}$ & & & & \\
\hline $\mathrm{E}$ & 0.33 & 0.20 & $0.79^{* * *}$ & $0.96^{* * *}$ & & & \\
\hline SD & 0.30 & -0.05 & -0.22 & -0.33 & -0.31 & & \\
\hline SA & -0.16 & -0.09 & 0.05 & -0.10 & -0.17 & $-0.35^{*}$ & \\
\hline SAI & $0.42^{*}$ & 0.08 & -0.05 & -0.18 & -0.22 & $0.73^{* *}$ & 0.25 \\
\hline \multicolumn{8}{|l|}{ Common reed } \\
\hline $\mathrm{OA}$ & -0.22 & & & & & & \\
\hline$P_{\mathrm{N}}$ & $0.36^{*}$ & 0.18 & & & & & \\
\hline$g_{\mathrm{s}}$ & 0.31 & 0.10 & $0.64^{* * *}$ & & & & \\
\hline $\mathrm{E}$ & $0.38^{*}$ & -0.01 & $0.51^{* *}$ & $0.93^{* * *}$ & & & \\
\hline SD & -0.06 & $-0.45^{*}$ & 0.04 & -0.31 & $-0.42 *$ & & \\
\hline SA & 0.07 & $0.34^{*}$ & 0.03 & 0.18 & 0.33 & $-0.81^{* * *}$ & \\
\hline SAI & -0.09 & $-0.48^{*}$ & 0.11 & -0.26 & -0.29 & $0.77^{* * *}$ & $-0.34^{*}$ \\
\hline
\end{tabular}

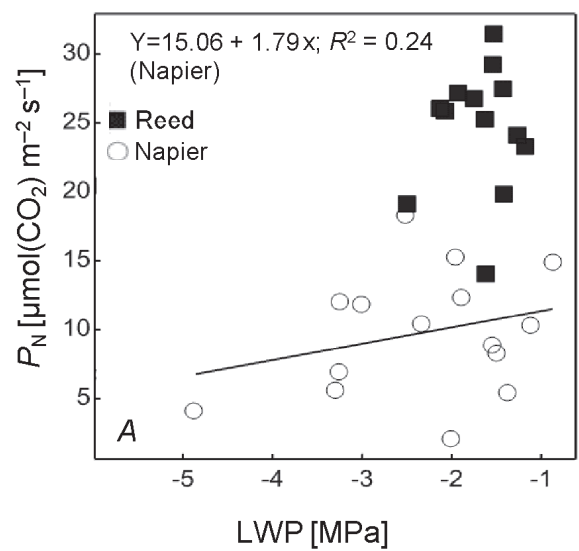

(Fig. 2E,F). Napier grass under $\mathrm{eCO}_{2}$ and high temperature had lower $E$ than that under $\mathrm{aCO}_{2}$ and low temperature. Both grasses had a higher WUE under $\mathrm{eCO}_{2}$ irrespective of temperature (data not presented).

\section{Responses to water stress at $\mathrm{eCO}_{2}$ and high temperature:} Predawn or midday LWP in the experiment III was similar for both grass species under $\mathrm{eCO}_{2}$ and $\mathrm{aCO}_{2}$ after watering withdrawal (Fig. $3 A$ ). However, $P_{\mathrm{N}}$ was higher for common reed (Fig. $3 B$ ) under either of the $\mathrm{CO}_{2}$ concentrations; a trend that was maintained for $E$ (Fig. $3 C$ ).

Exposure of the grasses to $\mathrm{eCO}_{2}$ and high temperature (Table 2 ) increased OA by $22 \%$ in Napier grass and by $10 \%$ in common reed, compared to $\mathrm{aCO}_{2}$ and low temperature conditions. $\mathrm{WUE}_{\mathrm{I}}$ for the two grasses was generally higher when exposed to $\mathrm{eCO}_{2}$ both during water stress (before watering) and after alleviation of the stress (after watering), but the gains in $\mathrm{WUE}_{\mathrm{I}}$ arising from exposure to $\mathrm{eCO}_{2}$ was always larger in Napier grass than that in common reed, being on average $58 \%$ in Napier grass and
Fig. 4. Correlations between $(A)$ midday leaf water potential (LWP) and carbon assimilation and $(B)$ stomatal density and stomatal area for Napier grass and common reed. Data were pooled from experiments I and III. Both stomatal area and density were obtained at the end of the experiments.
$15 \%$ in common reed (Table 2).

Exposure to $\mathrm{eCO}_{2}$ under high temperature resulted in similar stomatal density in Napier grass despite $23 \%$ increase on the abaxial leaf surface (Table 3). Also, there was no significant impact on stomatal area or leaf area in both species. The leaves of Napier grass were 31 times larger than those of common reed under either $\mathrm{CO}_{2}$ concentration. The leaf to stem ratio was not significantly affected by exposure to $\mathrm{eCO}_{2}$ in Napier grass, but it was reduced by $19 \%$ in common reed; this variable was generally twice as large in Napier grass as in common reed. Exposure to $\mathrm{eCO}_{2}$ increased biomass by $12 \%$ in Napier grass, but had no impact on common reed.

Correlations amongst physiological response variables: Significant $r$ were found amongst several attributes of both Napier grass and common reed. Positive correlations included LWP and $P_{\mathrm{N}}, P_{\mathrm{N}}$ and $g_{\mathrm{s}}$ or $E$, stomatal area and SAI, while negative correlations were between stomatal density and stomatal area in both grasses (Table 4). 
Coefficients of determination $\left(R^{2}\right)$ were strong between stomatal density and stomatal area in common reed only, while those between LWP and $P_{\mathrm{N}}$ in both grasses were weak, including stomatal density and stomatal area in Napier grass (Fig. 4).

\section{Discussion}

There was a strong contrast in the responses of the two grass species to water stress when exposed to either concentration of $\mathrm{CO}_{2}$ or temperature. While Napier grass is adapted to warm mesic environments, common reed is a wetland species, even though some populations are adapted to desert environments where sub-surface water is available. The differences between the two species could be explained by their stomata characteristics, as evident in the rates of $E$ and their capacity for osmotic adjustment. The common reed consistently had larger $E$ than Napier grass even when subjected to periods of watering withdrawal of up to three weeks (Fig. 1E,F), and more so with exposure to $\mathrm{eCO}_{2}$ than to $\mathrm{aCO}_{2}$. A poor stomatal control in the riparian common reed was clearly evident when the plants were subjected to water and temperature stress over a 3 -week period, when its $E$ was always larger than that in Napier grass by at least a factor of 2 at $\mathrm{aCO}_{2}$ and a factor of 4 at $\mathrm{eCO}_{2}$ (Fig. 3). Mesic species such as Napier grass are known for their strong parsimony in water use even when water is relatively available during periods of high vapour pressure deficits and evaporative demand (Yunusa et al. 2010, Ocheltree et al. 2013) as observed in this study (Table 2). Thus, the relatively larger OA in Napier grass did not confer any advantage in terms of $E$ (Fig. 1) in the 6-week-old grass, and was consistent with experience of Aranda et al. (2008), who found no significant impact of $\mathrm{eCO}_{2}$ on $\mathrm{OA}$ in oak (Quercus suber). This suggested that at this early stage of growth, tissue water status and water use were mostly a function of canopy development and the capacity of gas exchange sites, i.e. bulk stomatal conductance. Water stress induced stomatal closure in mesic species of grasses, such as Blue grama grass (Bouteloua gracilis) and western wheatgrass ( $P$. smithii) (Morgan et al. 2001). Further, restrained stomatal opening is also enhanced with exposure to $\mathrm{eCO}_{2}$ as found in maize Zea mays (Bunce 2004, Bernacchi et al. 2007).

A strong stomatal control of $E$ was observed in Napier grass subjected to low soil-water supply and high temperature (Mwendia et al. 2013), and a similar mechanism could explain its capacity to more quickly rehydrate its tissue than the common reed, following a period of stress when the grasses were about 12 weeks old (Fig. 2). The advantage in tissue water recovery in Napier grass over common reed was even stronger under $\mathrm{eCO}_{2}$ when the increase in midday LWP for Napier grass was about 2.5 $\mathrm{MPa}$ compared to $1.4 \mathrm{MPa}$ with $\mathrm{aCO}_{2}$; much larger than the corresponding values for the common reed of $\sim 0.0 \mathrm{MPa}$ and $<0.5 \mathrm{MPa}$, respectively. Ward et al. (1999) observed a more rapid recovery in LWP from -1.78 to $-0.53 \mathrm{MPa}$ in the $\mathrm{C}_{4}$ A. retroflexus, compared to -1.80 to $-0.78 \mathrm{MPa}$ in $\mathrm{C}_{3}$ A. theophrasti, within $7 \mathrm{~d}$ after a drought event lasting $4 \mathrm{~d}$. The LWP was less negative under $\mathrm{eCO}_{2}$ conditions than that under $\mathrm{aCO}_{2}$ after $7 \mathrm{~d}$ of recovery. In this study, differences in recovery between the both grasses could also be partly the result of their $\mathrm{OA}$, which was larger in Napier grass than in the common reed and was consistent with the reported larger OA for $\mathrm{C}_{4}$ than that of $\mathrm{C}_{3}$ (Quian and Fry 1997). The Napier grass had almost twice the $\mathrm{OA}$ as the common reed at age of 16 weeks (Table 2). The OA in both species at this age was much larger than observed earlier at the 6 weeks of age (Table 2); this increase was about twice as large in Napier grass compared to the common reed (Table 2), and could facilitate recovery in tissue hydration, especially in the former grass.

Carbon assimilation was consistently higher for the common reed than that for Napier grass at either concentrations of $\mathrm{CO}_{2}$, except when the latter had maintained significantly higher midday LWP as was the case following two weeks without watering at five weeks of age (Fig. $1 A-D)$ and soon after watering at either $\mathrm{CO}_{2}$ concentration at eight weeks of age (Fig. $2 A-D$ ). Carbon assimilation was therefore quite sensitive to LWP in Napier grass and there was stronger correlation between the two variables in this grass compare to that in the common reed (Table 4). Furthermore, $\mathrm{C}$ assimilation was also strongly and positively correlated with $g_{\mathrm{s}}$ and $E$, more so in the Napier grass than in the common reed (Fig. 4). Napier grass therefore, appears to maximize its carbon assimilation when tissue hydration is favourable, bolstered by investment in extensive canopy, unlike in the common reed. Napier grass, is also highly sensitive to unfavourable environment. However, the consistently higher SAI for the common reed conferred significant advantage in terms of $P_{\mathrm{N}}$ over Napier grass, and was quite contrary to the generally higher $P_{\mathrm{N}}$ reported for $\mathrm{C}_{4}$ compared to $\mathrm{C}_{3}$ (Ward et al. 1999, Morgan et al. 2001). Although below-ground carbon allocation was not assessed, it is likely that common reed with the high $P_{\mathrm{N}}$ was investing into the rhizomes. In the current study, it appears that the water stress induced stomatal closure observed in Napier grass obviated the inherent advantage of its superior $\mathrm{C}_{4}$ photosynthetic mechanism. This is possible given $\mathrm{C}_{4}$ photosynthesis is highly sensitive to low leaf water status, and results in rapid decreases in $P_{\mathrm{N}}$ and stomatal conductance (Ghannoum 2009).

Gross dry matter (DM) production was higher in the $\mathrm{C}_{4}$ Napier grass, because its canopy was consistently much larger than that of the $\mathrm{C}_{3}$ common reed. Its low SAI notwithstanding, a large canopy conferred a greater total surface area for gas exchange, along with light interception, on the Napier grass, relative to small canopy in the common reed. For instance, at 17 weeks of age, total stomata area $(\mathrm{SAI} \times \mathrm{LA})$ was $216 \mathrm{~cm}^{2}$ per plant for Napier grass compared to $17 \mathrm{~cm}^{2}$ per plant for the common reed (Table 3), i.e. a difference by a factor $>12$. This explains the consistently higher gross water use and dry matter accumulation for the Napier grass than that in the common reed, and this difference was further enlarged by exposure to $\mathrm{eCO}_{2}$, especially at later stages of growth. While $\mathrm{eCO}_{2}$ increased canopy size in both species by up to a factor of 2 in the early stage, the increase in LA was $10 \%$ in Napier grass compared to no apparent increase in the common reed 
at $17^{\text {th }}$ week of age (Table 3 ). It is noteworthy, however, that the difference in gross water use between the Napier grass and the common reed was generally lesser than a factor of 2.0, which meant that the specific water use (water use/LA) was substantially higher for the reed than that of the Napier grass. The specific water use (SWU) under $\mathrm{eCO}_{2}$ was $170 \mathrm{~mm} \mathrm{~m}^{-2}$ for Napier grass and 2,640 mm $\mathrm{m}^{-2}$ for the reed, while the corresponding specific biomass production (SBP) was $47 \mathrm{~g} \mathrm{~m}^{-2}$ for Napier grass and $110 \mathrm{~g} \mathrm{~m}^{-2}$ for the reed (Table 3). Under $\mathrm{aCO}_{2}$, the SWU was largely unchanged in the reed but marginally increased in the Napier grass, while SBP was marginally lower in both grasses. The higher productivity water-use efficiency $\left(W_{\mathrm{p}}\right.$ ) for Napier grass (Table 3 ) was therefore due to this species using just a fraction $(<6 \%)$ of water/LA compared to common reed, despite its specific productivity being about $50 \%$ of that obtained in the common reed.

$P_{\mathrm{N}}$ in $P$. australis observed in the current study (25$35 \mu \mathrm{mol} \mathrm{m} \mathrm{m}^{-2} \mathrm{~s}^{-1}$ ) were higher than those of the native

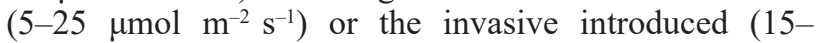
$25 \mu \mathrm{mol} \mathrm{m}^{-2} \mathrm{~s}^{-1}$ ) P. australis in the eastern USA studied by Mozdzer and Zieman (2010). These data suggest that the local $P$. australis material used in this study is probably not much different from that present at least in some other parts of the world.

More sensitive stomatal control in Napier grass appears to be the key for its maintenance of the favourable tissue hydration than that achieved by the common reed. While $E$ was subdued in Napier grass by exposure to $\mathrm{eCO}_{2}$, common reed maintained a similar $E$ rate under both ambient $\mathrm{CO}_{2}$ exposures (Fig. $1 E$ ). This was despite the stomatal area for Napier grass being $>1.5$ larger than that for common reed, especially on the abaxial surface (Table 3). Furthermore, the lower stomatal density on both leaf surfaces of the common reed did not constrain $E$ relative to Napier grass (Table 2). More sensitive stomatal control was observed in $\mathrm{C}_{4}$ species, including Napier grass (Mwendia et al. 2013) and maize, relative to $C_{3}$ species (Lopes et al. 2011). Hence, stomatal morphology (density, size, and area) per se appeared to have limited impact on $E$ and $\mathrm{CO}_{2}$ assimilation in these two grasses. Paoletti and Gellini (1993) argued that improvements in instantaneous WUE under $\mathrm{eCO}_{2}$ are more dependent on stomatal function (opening and closing) than on morphology. A similar conclusion was drawn by Tricker et al. (2005) after a 5-year study that found weak or no association between stomatal density or stomatal index with WUE in clones of $\mathrm{C}_{3}$ tree species (Populus alba and P. nigra) exposed to $\mathrm{eCO}_{2}$. The inverse relationship between stomatal density and stomatal area in the two grasses is consistent with the common observation of other plant species, including 35 tree species (Carmargo and Marenco 2011), okra, and tomato (Kamaluldeen et al. 2014).

Conclusions: Exposure to elevated $\mathrm{CO}_{2}$ concentration enhanced the capacity for maintaining favourable tissue hydration when the grasses were subjected to low soilwater supply. Under such conditions, the $\mathrm{C}_{4}$ Napier grass had a better tissue hydration through control of $E$ and osmotic adjustment resulting in higher $\mathrm{C}$ assimilation per unit water use as the soil dries: this grass also recovered more rapidly than the common reed upon the relief of water stress. Thus, the Napier grass displayed a superior capacity for tolerating water stress and high daytime temperatures; it maintained higher tissue hydration, more so when exposed to $\mathrm{eCO}_{2}$, than did the common reed. The hardiness of Napier grass observed here was consistent with its capacity to maintain favourable tissue hydration and stomatal conduction during dry periods when grown on a relatively coarse (sandy-clay) soil in East Africa (Mwendia et al. 2017). Although Napier grass and the common reed are adapted to quite different habitats, this study reveals the contrasting mechanisms deployed by these grasses when subjected to the same stressors; Napier grass exerted strong control of $E$, and executed larger OA than that of common reed. We demonstrated here that Napier grass would tolerate and remain viable under the projected increases in atmospheric $\mathrm{CO}_{2}$ concentrations to $550 \mathrm{ppm}$ and temperature of $4.8^{\circ} \mathrm{C}$ by the end of the $21^{\text {st }}$ century (IPCC 2014).

\section{References}

Aranda I., Puértolas J., Pardos M. et al.: Elevated atmospheric $\mathrm{CO}_{2}$ does not modify osmotic adjustment to light and drought in the Mediterranean Oak Quercus suber L. - Invest AgrarSist R. 17: 3-9, 2008.

Bajji M., Lutts S., Kinet J.: Water deficit effects on solute contribution to osmotic adjustment as a function of leaf ageing in three durum wheat (Triticum durum Desf.) cultivars performing differently in arid conditions. - Plant Sci. 160: 669-681, 2001.

Bernacchi C.J., Kimball B.A., Quarles D.R. et al.: Decreases in stomatal conductance of soybean under open air elevation of $\mathrm{CO}_{2}$ are closely coupled with decreases in ecosystem evapotranspiration. - Plant Physiol. 143: 134-144, 2007.

Blum A., Munns R., Passioura J.B., et al.: Genetically engineered plants resistant to soil drying and salt stress: how to interpret osmotic relations. - Plant Physiol. 110: 1051-1053, 1996.

Boonman J.G.: East Africa's Grasses and Fodders, their Ecology and Husbandry. Pp. 350. Kluwer Academic Publ., Dordrecht 1993.

Bunce J.A.: Carbon dioxide effects on stomatal responses to the environment and water-use by crops under field conditions. Oecologia 140: 1-10, 2004.

Carmargo M.A.B., Arenco R.A.M.: Density, size and distribution of stomata in 35 rain forest tree species in Central Amazonia. - Acta Amazon. 41: 205-212, 2011.

Eamus D., Jarvis P.G.: The direct effects of increase in the global $\mathrm{CO}_{2}$ concentration on natural and commercial temperate trees and forests. - Adv. Ecol. Res. 19: 1-55, 1989.

Fernandéz R.J., Wang M., Reynolds J.F.: Do morphological changes mediate plant responses to water-stress? A steadystate experiment with two C4 grasses. - New Phytol. 155: 79-88, 2002.

Ghannoum O.: C4 photosynthesis and water-stress. - Ann. Bot.London 103: 635-644, 2009.

Giridhar K., Samireddypalle A.: Impact of climate change on forage availability for livestock. - In: Sejian V., Gaughan J., Baumgard L., Prasad C. (ed.): Climate Change Impact on Livestock: Adaptation and Mitigation. Pp. 97-112. Springer, New Delhi 2015.

Gucker C.L.: Phragmites australis. - In: Fire Effects Information 
System, U.S. Department of Agriculture, Forest Service. Rocky Mountain Research Station, Fire Sciences Laboratory. Available: http://www.fs.fed.us/database/feis/, 2008.

Intergovernmental Panel on Climate Change (IPCC): Climate Change 2014: Synthesis Report, 2014. http://www.ipcc.ch/ pdf/assessment-report/ar5/syr/SYR_AR5_SPMcorr1.pdf [accessed 19 December 2017].

Kamaluldeen J., Yunusa I., Zerihun A. et al.: Uptake and distribution of ions reveal contrasting tolerance mechanisms for soil and water salinity in okra (Abelmoschus esculentus) and tomato (Solanum esculentum). - Agr. Water Manage. 146: 95-104, 2014.

Karkanis A., Bilalis D., Efthimiadou A.: Architectural plasticity, photosynthesis and growth responses of velvet leaf (Abutilon theophrasti Medicus) to water-stress in a semiarid environment. - Aust. J. Crop Sci. 5: 369-374, 2011.

Klingebiel A.A., Montgomery P.H.: Land Capability Classification. Agriculture Handbook No. 210. Pp. 1-25. US Department of Agriculture, Washington DC 1961.

Knapp A.K., Cocke M., Hamerlynck E.P. et al.: Effect of elevated $\mathrm{CO}_{2}$ on stomatal density and distribution in a $\mathrm{C} 4$ grass and a C3 forb under field conditions. - Ann. Bot.-London 74: 595599, 1994.

Köbbing J.F., Thevs N., Zerbe S.: The utilisation of reed (Phragmites australis): a review. - Mires Peat 13: 1-14, 2013.

Lambers H., Chapin F.S., Pins T.L.: Plant Physiological Ecology. Pp. 101-223. Springer Science, New York 2008.

Lammertsma E.I., de Boer H.J., Dekker S.C. et al.: Global $\mathrm{CO}_{2}$ rise leads to reduced maximum stomatal conductance in Florida vegetation. - P. Natl. Acad. Sci. USA 108: 4035-4040, 2011.

Lecain D.R., Morgan J.A., Mosier A.M. et al.: Soil and plant water relations determine photosynthetic responses of $\mathrm{C}_{3}$ and $\mathrm{C}_{4}$ grasses in a semi-arid ecosystem under elevated $\mathrm{CO}_{2}$. Ann. Bot.-London 92: 41-52, 2003.

Liu W., Liu G., Zhang Q.: Shoreline vegetation in the Danjiangkou reservoir: Characteristics, related factors, and differences with adjacent riverine wetlands. - Clean-Soil Air Water 42: 10141021, 2014.

Lopes M.S., Araus J.L., van Heerden P.D.R. et al.: Enhancing drought tolerance in C4 crops. - J. Exp. Bot. 62: 3135-3153, 2011.

Mallett K., Orchard O.E.: Flora of Australia, Vol. 43, Poaceae 1, Introduction and Atlas. Pp. 307. CSIRO Publishing, Clayton 2002.

Minitab Inc.: Minitab Statistical Software, release 15 for Windows. Minitab Inc. State College, Pennsylvania 2007.

Morgan J.A., Lecain D.R, Mosier A.R. et al.: Elevated $\mathrm{CO}_{2}$ enhances water relations and productivity and affects gas exchange in $\mathrm{C}_{3}$ and $\mathrm{C}_{4}$ grasses of the Colorado shortgrass steppe. - Glob. Change Biol. 7: 451-466, 2001.

Mozdzer T.J., Zieman J.C.: Ecophysiological differences between genetic lineages facilitate the invasion of non-native Phragmites australis in North American coast wetlands. - J.
Ecol. 98: 451-458, 2010

Mwendia S.W., Yunusa I.A.M., Sindel B.M. et al.: Assessment of Napier grass accessions in lowland and highland tropical environments in east Africa: Productivity and forage quality. - Exp. Agr. 53: 27-43, 2016.

Mwendia S.W., Yunusa I.A.M., Sindel B.M. et al.: Assessment of Napier grass accessions in lowland and highland tropical environments in east Africa: water stress indices, water use and water use efficiency. - J Sci Food Agric. 97: 1953-1961, 2017.

Nilsen E.T., Sharifi M.R., Rundel P.W. et al:: Diurnal and seasonal water relations of the desert phreatophyte Prosopis glandulosa (honey mesquite) in the Sonoran desert of California. - Ecology 64: 1381-1393, 1983.

Ocheltree T.W., Nippert J.B., Prasad P.V.V.: Stomatal responses to changes in vapour pressure deficit reflect tissue-specific differences in hydraulic conductance. - Plant Cell Environ. 37: 132-139, 2013.

Paoletti E., Gellini R.: Stomatal density variation in beech and holm Oak leaves collected over 200 years. - Acta Oecol-Oec Plant. 14: 173-178, 1993.

Pearcy R.W., Berry J.A., Bartholoomew B.: Field photosynthetic performance and leaf temperatures of Phragmites communis under summer conditions in Death Valley, California. Photosynthetica 8: 104-108, 1974.

Quian Y.L., Fry J.D.: Water relations and drought tolerance of four turfgrasses. - J. Am. Soc. Hortic. Sci. 122: 129-133, 1997.

Ripley B.S., Gilbert M.E., Ibrahim D.G. et al:: Drought constraints on $\mathrm{C} 4$ photosynthesis: stomatal and metabolic limitations in $\mathrm{C} 3$ and $\mathrm{C} 4$ subspecies of Alloteropsis semialata. - J. Exp. Bot. 58: 1351-1363, 2007.

Tricker P.J., Trewin H., Kull O. et al.: Stomatal conductance and not stomatal density determines the long-term reduction in leaf transpiration of poplar in elevated $\mathrm{CO}_{2}$ - Oecologia 143: 652-660, 2005.

Tudsri S., Jorgensen S.T., Riddach P. et al.: Effects of cutting height and dry season closing date on yield and quality of five Napier grass cultivars in Thailand. - Trop. Grasslands 36: 248-252, 2002.

Tyree M.T., Alexander J.D.: Plant water relations and the effects of elevated $\mathrm{CO}_{2}$ : a review and suggestions for future research. - Vegetatio 104: 47-62,1993.

Wall G.W., Brooks T.J., Adam R. et al.: Elevated atmospheric $\mathrm{CO}_{2}$ improved sorghum plant water status by ameliorating the adverse effects of drought. - New Phytol. 152: 231-248, 2001.

Ward J.K., Tissue D.T., Thomas R.B. et al.: Comparative responses of model $\mathrm{C}_{3}$ and $\mathrm{C}_{4}$ plants to drought in low and elevated $\mathrm{CO}_{2}$. - Glob. Change Biol. 5: 857-867, 1999.

Yunusa I.A.M., Aumann C.D., Rab M.A. et al.: Topographical and seasonal trends in transpiration by two co-occurring Eucalyptus species during two contrasting years in a low rainfall environment. - Agr. Forest Meteorol. 150: 1234$1244,2010$.

(C) The authors. This is an open access article distributed under the terms of the Creative Commons BY-NC-ND Licence. 